\title{
TRANSPORT AND LOGISTICS AND THEIR INFLUENCE ON EXPORT COSTS
}

The paper deals with the role of transport and logistics as they relate to exports. We searched for the impact of transport and logistics on exports using transaction dynamics as described by Coase and Williamson. We deal with the costs of exchange using international sales contracts where the traditional calculation structure, based primarily on costs of delivery is extended with transaction costs. Furthermore, we measure the impact of such adjusted costs of exchange on the added value using Porter's methods and determine which costs have the nature of investment. Finally, the effect of resource implementation into information and communication technologies and the related changes in transport and logistics are presented (in the paper).

Keywords: Transport and logistics, export costs, information and communication technologies.

\section{Introduction}

Transport and logistics belong to the category of services in the international trade, which cannot be currently separated from export and import of goods or substituted by another shipment technology. They have been a standard calculation item in the export costs structure for a long time, where they constitute the so-called delivery costs, and, in addition to other calculated exchange costs (export costs) they influence the added value in the export price.

The research of a calculation structure of exchange costs in export prices is a core subject of this paper. In this context, we focused on two problem areas. The first area dealt with three issues: 1 . In what way can the commonly used calculation structure of export costs be expanded to include transaction costs as understood by Coase and Williamson? 2. Does export involve any exchange costs whose increase can have positive impact on the value added? 3 . What are the effects of their mutual substitution? The second problem area focused on interpretation of the changing status of transport and logistics in export in relation to including transaction costs into export calculation and the related influence of information and communication technologies.

The main theoretical background was presented by Porter's theories of competitiveness [1 and 2], mainly the new business models of industrial companies in relation to implementation of modern information technologies (the third IT wave and production of smart connected products) and to theories of transaction costs according to Coase [3 and 4] and Williamson [5], which deal with contracts and ownership rights on the company level in the so-called golden triangle: contract, ownership and transaction costs. We used empirical research results published in works on transport demand of commodities in the international trade [6], on time as a barrier to trade [7 and 8], on resources and capacities influencing company export performance [9], on exchange costs [10], on alternative methodology to estimate the size of the transaction cost sector [11], on the empirical estimates of transaction costs [12].

The contribution is divided into three parts: the first part introduces a hypothetical calculation structure of export costs including transaction costs according to Coase and Williamson; the second part deals with methodology of measuring the value of export costs (exchange costs), as well as measuring the effects of their substitution and the follow-up specification of costs with positive or negative character in relation to their impact on the value added; in the third part, we used our findings regarding the importance of including resources in export costs of positive character to interpret the changing status of transport and logistics in time, with a special focus on information and communication technologies.

\footnotetext{
* ${ }^{1}$ Heda Hansenova, ${ }^{2}$ Vaclav Cempirek, ${ }^{2}$ Petr Novak

${ }^{1}$ Department of International Trade, Faculty of Commerce, University of Economics in Bratislava, Slovakia

${ }^{2}$ Department of Transport Technology and Control, Jan Perner Transport Faculty, University of Pardubice, Czech Republic

E-mail: hedhan@yahoo.com
} 


\section{Hypothetical calculation structure of export costs according to Coase and Williamson}

Creating the hypothetical structure of export costs, we used an idea published in the article of Alexandra Benham and Lee Benham entitled "The Cost of Exchange“, where they state (on page 3):

"The cost of exchange is defined as the opportunity cost faced by an individual to obtain a specified good using a given form of exchange within a given institutional setting. More specifically, the cost of exchange $\mathrm{C}_{\mathrm{i} i \mathrm{~km}}$ is defined as the opportunity cost in total resources money, time, and goods for an individual with characteristics $i$ to obtain a good $j$ using a given form of exchange $\mathrm{k}$ in institutional setting $\mathrm{m}$, where the form of exchange refers to the type of market (formal vs. informal) in which the exchange takes place, or to dimensions such as pecuniary versus barter exchange.“

In our research we specified:

a) the form of transaction that is international sales contract and its transaction mechanism heading to the change of the ownership, whereby the background for this idea was the Williamson's premise of the bounded rationality and opportunism,

b) price wedge between the price of good in the country of import on the clause of DDP (Delivery Duty Paid) and the price of good in the country of export on the clause of EXW, the owner of the good in EWX is the sailing exporter and the owner of the good in DDP is the purchasing importer.

The price wedge in the export price [13 and 14]; involves a complex of costs whose structure can be viewed from many perspectives. One kind of such division is the division of legal and illegal costs (in the context of the Global Competitiveness Index data), then the cost of a positive nature (investment nature, in the context of global sustainability indices databases) and the cost of a negative nature (one-time costs - from the traditional perception of the cost structure export prices [15 and 16].

In this study of the contribution of the replacement, the importance of time (speed of delivery and interest) and the physical space (the capacity of vehicles and delivery) are emphasized and referred to as an indirect financial expense or income. For completeness, in the meaning of new institutional theories, included into a hypothetical structure of exchange costs were also the positive and negative externalities by Williamson [5]. The following are included in the export price as being related to the function of the exchange costs: marketing, conclusion, management and enforcement of the contracts, delivery, financing, risk, administrative costs (duties, taxes) associated with crossing the border, information and communications, knowledge, ethics and ecology. It is a whole complex of exchange costs in export price needed to be done to change the ownership of the goods from exporter to importer and maintain the sustainability of commercial transactions [17].

Fig. 1 shows a hypothetical structure of costs of exchange in export price.

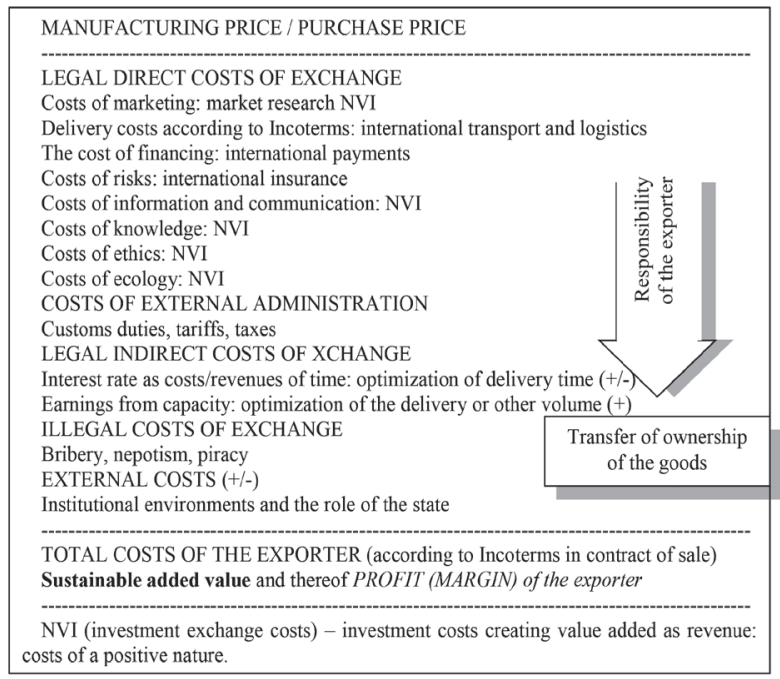

Fig. 1 Hypothetical structure of costs exchange in export price in contract of sale. Source: HANSENOVA, H. et al: Transport and its impact on transaction costs in export prices - draft of model of export prices. In: Cesko a Slovensko v medzinarodnom obchode a podnikani

2012, Medzinarodna konkurencieschopnost a nove vyzvy vyvolane ekonomickou krizou: zbornik prispevkov z 12. medzinarodnej vedeckej konferencie: Praha, 2012.

\section{Methodology of the measurement of export costs: model TEAT}

We use the outcomes from the dissertation Transaction Costs and Their Influence on the Competitiveness of the Slovak and EU Export [18]. In this paper, the methodology of measurement and management of export costs based on model TEAT (Transaction, Export, Added value, Transportation) was created. In Table 1 the Transaction Costs and Their Influence on the Competitiveness of the Slovak and EU Export for the territory of 143 countries from the world are given. Export costs are measured per capacity of 1 TEU container of the weight of $10 t$ or of the good value of 20000 USD. It is evident from Table 1 that if any cost issue from the axis $\mathrm{x}$ increases by $1 \%$, the rest of the costs issues change according to the indexes on the axis $y$. It is applicable for the given period of years for each examined country. The second important evidence of the outcome of the model TEAT is the confirmation of the existence of the positive (investment) character costs and the costs of the negative (the only single use of the expenditure) character and the effect of the increase of the positive character costs in consideration of the added value. 
Transaction Costs and Their Influence on the Competitiveness of the Slovak and EU Export

Table 1

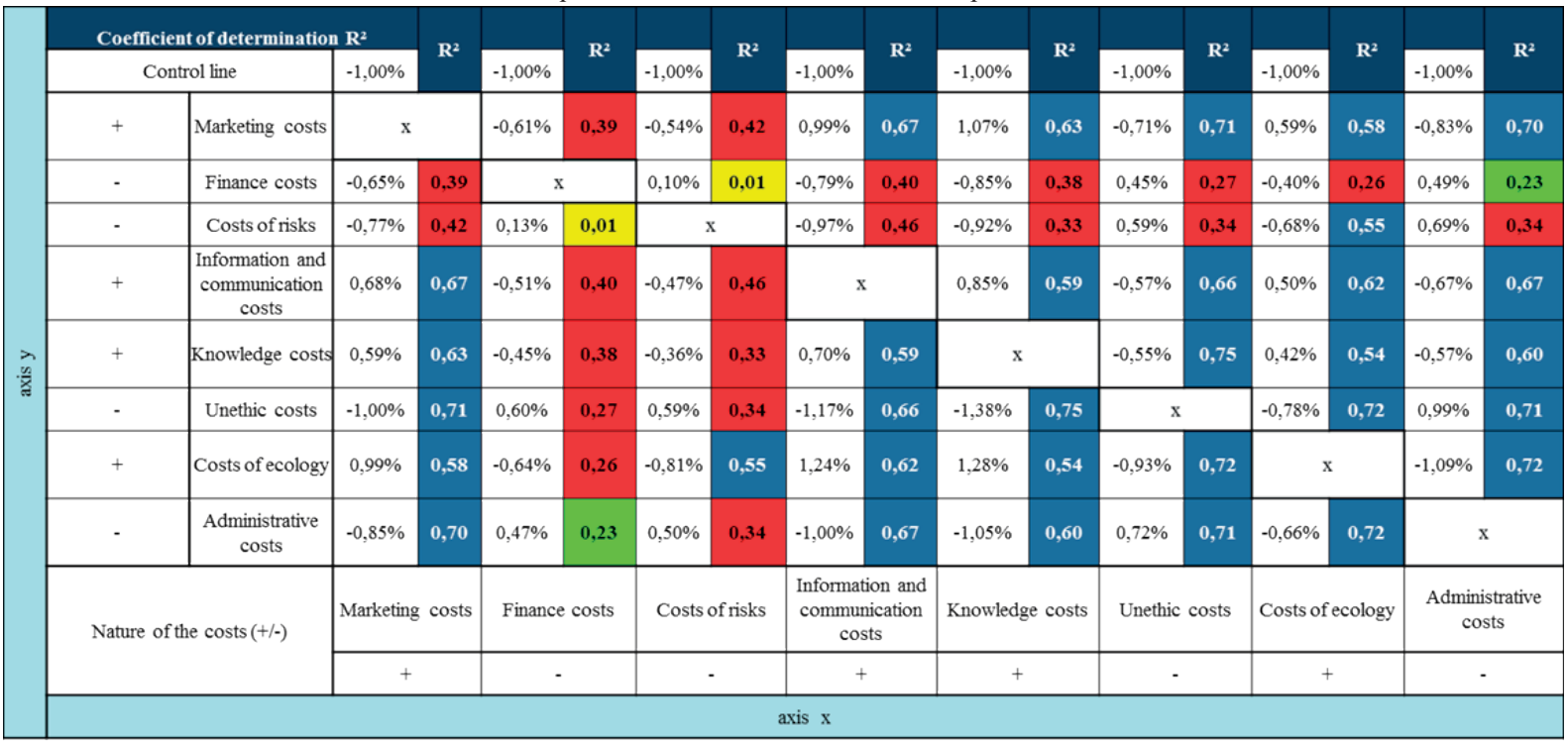

Source: MINARIK, M. 2014: Transaction Costs and Their Influence on the Competitiveness of the Slovak and EU Export (dissertation)

\subsection{The creation of the database}

When creating the database, the secondary data of the qualitative character from the Index of the Global Competitiveness 2012-2013 (GCI 2012-2013) and the secondary data of the quantitative character of the Doing Business 2013 (DB 2013) were used. It was necessary to focus on the part that deals with the measurement of the export costs per 1 TEU container in DB 2013.

8 indicators were selected out of all of the GCI 2012-2013 indicators that approximate as best as possible to the cost issues in the adjusted model of the export price:

Manufacturing price/Purchase price on the clause EXW Export costs per 1TEU on the clause FOB

Marketing Costs $(\mathrm{NM})=$ Extent of Marketing

Finance Costs (NF) $=$ Soundness of Banks

Costs of Risks (NR) $=$ Business Costs of Crime and Violence Information and Communication Costs (NIK) $=$ Firm-Level of Tech. Absorption

Knowledge Costs $(\mathrm{NZ})=$ Extent of Staff Training

Unethical Costs $(\mathrm{NN})=$ Ethical behaviour of firms

Ecology Costs (NE) = Quality of Overall Infrastructure

Administrative costs (NA) $=$ Burden of Customs Procedures

Own Total Exporter Costs Added Value/ Margin/Profit
Each out of 8 selected indicators (I) that form the structure of the export price is defined within the GCI 2012-2013 by a value that belongs to the interval $\langle 0 ; 7\rangle$. The higher value is the probability of the application of the given indicator. The values are localized in the database A (casaespana.sk/databaza.xls). Furthermore, the database A was modified twice for the research needs in the following way:

\subsection{Modification of the database}

$$
(I \times 100) / 7=P
$$

For I - marketing, information and communication, knowledge and ecology costs

$[(7-I) \times 100] / 7=P$

For I - Finance costs, costs of risks, unethical costs and administrative costs

The result value of $\mathrm{P}$ determines the number of cases out of 100 , when the given indicator is applicable and contributes to the growth of the export price of 1 TEU container (database B, see casaespana.sk/databaza.xls).

The sum of all values of the cost issues for each country out of the 143 was calculated and the given values were modified one more time in a proportional way for a better interpretation in such a way that the sum of all of the cost issues was 100 for each country. The given value indicates $100 \%$. 
$\mathrm{X}=\frac{100 \times P^{\prime}}{\sum P_{i}^{\prime}}$

$\mathrm{X}$ - adjusted indicator ( $2^{\text {nd }}$ modification) for the need of the analysis (each cost issue that belongs to the model),

$\mathrm{P}^{\prime}$ - adjusted indicator from the $1^{\text {st }}$ modification for the need of the analysis (each cost issue that belongs to the model),

$\mathrm{i}$ - means 8 cost issues.

The result values including the export costs per 1 TEU container on the clause $\mathrm{FOB}^{1}$ INCOTERMS are localized in the database $\mathrm{C}$ (casaespana.sk/databaza.xls). Furthermore, a function was created; the export costs are equal to the sum of the 8 cost issues:

$$
E N=f(N M, N F, N R, N Z, N I K, N N, N E, N A)
$$

Export costs (EN) are given in absolute value in USD and each cost issue on the other side of the function is given in \%. The sum of the $\%$ for each country is 100 . The difference is in the proportion of the particular cost issues for each country.

\subsection{The measurement of the dynamics of the export costs}

It was determined that there are two aspects of the evaluation of the dynamics of the export costs. The first one is the value of the particular cost issues that enter into the model of the export price (Fig. 2) and the second one is their mutual proportion (Fig. 3 ). These assertions are based on the finding that there are 4 cost issues of the positive nature and 4 cost issues of the negative nature out of 8 investigated.

The regression and correlation, which were realized, discovered the mutual relationship among all the pairs of the cost issues for the purpose to find out the alteration of each of them, if any issue changes by a certain percentage. The better interpretation produces a situation where, if a cost issue changes by $1 \%$, the extent of the change (in percentages) for the rest of the cost issues was determined. This property confirms the purpose of the research - not to increase the invoice price of the export but rather to try to logically rearrange the financial resources used so that it is possible to substitute the costs of multiple positive investments that improve the quality of the business environment for the costs of a single negative expenditure that decreases the quality of the business environment.

\subsection{The measurement of the information and communication costs in the structure of the export costs: model TEAT}

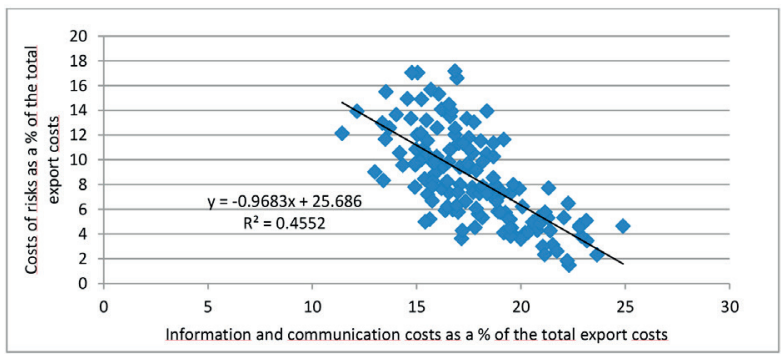

Fig. 2 Mutual relationship between the information and communication costs and the costs of risk. Source: MINARIK, M. 2014: Transaction Costs and Their Influence on the Competitiveness of the Slovak and EU Export (dissertation)

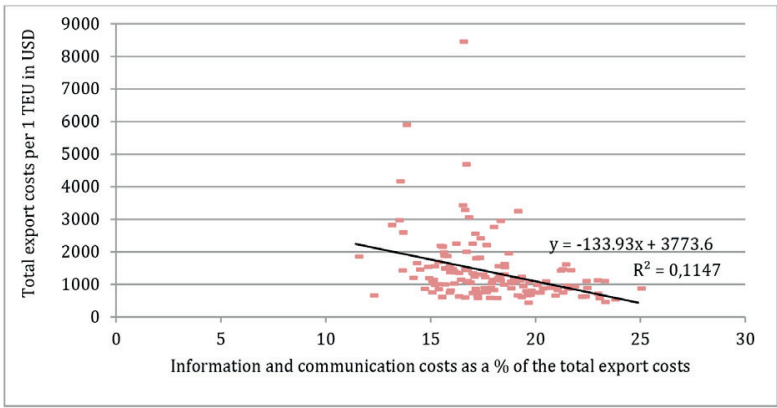

Fig. 3 Contribution of the information and communication costs to the total export costs per 1 TEU. Source: MINARIK, M. 2014: Transaction Costs and Their Influence on the Competitiveness of the Slovak and EU Export (dissertation)

\section{Determinants of changes in international transport and logistics}

The structure of the major determinants affecting the sustainable competitiveness of transport and logistics in the old and new economy is shown in Table 2. Transport and logistics are among the export costs sometimes classified as production transaction costs, [19] and the influence range of their application on business commodity transactions depends on the structure and complexity of the commercial market channels.

In the case of simple sales contracts with fixed prices, the position of transportation and logistics depends directly on used delivery clauses of INCOTERMS, which sometimes directly determine the modality of transport to be used, but mainly divide responsibilities of exporters and importers towards transport and logistics market. In the case of incentive price of delivery, or in the case of delivery of logistics chains, the place of delivery, risk and transition costs are set by means of other ways than the use of INCOTERMS: The most important function of transport and 
Determinants of changes in international transport and logistics

Table 2

\begin{tabular}{|l|l|l|}
\hline Old economy & New economy & $\begin{array}{l}\text { New economy after 2010 } \\
\text { (solution of the crisis) }\end{array}$ \\
\hline $\begin{array}{l}\text { Exogenous } \\
\text { development }\end{array}$ & $\begin{array}{l}\text { Endogenous } \\
\text { development }\end{array}$ & Sustainable development \\
\hline $\begin{array}{l}\text { International } \\
\text { transport } \\
\text { infrastructure }\end{array}$ & $\begin{array}{l}\text { Global transport } \\
\text { infrastructure }\end{array}$ & $\begin{array}{l}\text { Global, smart, } \\
\text { ecological transport } \\
\text { infrastructure, smart } \\
\text { production cluster/ } \\
\text { product cloud }\end{array}$ \\
\hline Transport modes & $\begin{array}{l}\text { Interoperability/ } \\
\text { Intermodality }\end{array}$ & $\begin{array}{l}\text { Amodality, intelligent, } \\
\text { green transport and } \\
\text { logistics }\end{array}$ \\
\hline $\begin{array}{l}\text { Rival information, } \\
\text { communication } \\
\text { with interface, rival } \\
\text { knowledge }\end{array}$ & $\begin{array}{l}\text { Information } \\
\text { technologies, } \\
\text { communication } \\
\text { technologies and } \\
\text { non-rival knowledge }\end{array}$ & $\begin{array}{l}\text { Integrated information } \\
\text { technologies, integrated } \\
\text { communication } \\
\text { technologies, } \\
\text { new technology stack/ } \\
\text { innovations }\end{array}$ \\
\hline $\begin{array}{l}\text { Added value } \\
\text { as a cost }\end{array}$ & $\begin{array}{l}\text { Added value as } \\
\text { revenue }\end{array}$ & $\begin{array}{l}\text { Added value as } \\
\text { sustainable revenue }\end{array}$ \\
\hline $\begin{array}{l}\text { Export price and } \\
\text { delivery costs } \\
\text { according to FOB } \\
\text { (free on board) }\end{array}$ & $\begin{array}{l}\text { Export price and } \\
\text { delivery costs } \\
\text { according to FCA } \\
\text { (free carrier) }\end{array}$ & $\begin{array}{l}\text { Export price and } \\
\text { sustainable delivery } \\
\text { costs according to FCA } \\
\text { (free carrier) }\end{array}$ \\
\hline Soure: HANSENOVA
\end{tabular}

Source: HANSENOVA, H. et al. 2012. Transport and its impact on transaction costs in export prices - draft of model of export prices. In Czech Republic and Slovakia in international trade and business 2012. Praha: Oeconomica Publishing house, 2012. ISBN 978-80-245-1876-3, s. 82-96. (modified)

logistics in export and import transactions is still the speed, quantity and quality of delivery, the information and good communication. An important interface that combines technology in transport and logistics with the creation of sustainable value added in export price on the basis of international sales contracts is the principle of interoperability, multimodality and amodality of goods delivery [20]. These technological principles allow not only to combine individual transport and logistics systems into a common chain of goods, but also to provide a comprehensive business solution with sole responsibility and liability. An important determinant of operation of these principles is integrated information and communications technology.

Now, in the third wave of IT transformation, products have become complex systems combining hardware, data storage, sensors and microprocessors, software and connectivity. These "smart, connected products" [2] have unleashed a new era of competition. It will bring further developments in integration of IT and communication technology in supply chain. Logistic and transport companies should be prepared for the new way of communication which requires building a new technology infrastructure. This so called "Technology Stack" includes modified hardware and software applications, network communication layer and a product cloud. Besides that an identity and security structure, external information sources and tools that connect the data with business system have to be involved [2].

\section{Conclusions}

The main goal was to point out to the possibility of connection between transaction costs and transport technology processes respecting the changes of ownership that are specified in the Contract of Sale in export. It has also taken into account the concrete economic category as lack, opportunism, usefulness and competitiveness. The aim of the research was to create a hypothetical costing structure of the replacement of the export price and to find its impact on the value added.

The objective was to confirm the existence of positive (investment) and negative (disposable) costs. The effect of substitution costs (negative costs reimbursement) was given.

It has been proven that if the recourses in ICT increase by $1 \%$, the rest of cost issues (administration, finance, risk management) are reduced. Export costs per 1TEU were calculated for each export (database of exports to 144 countries).

The proposed methodology has a lot of eliminations but the main goal was achieved. It was verified that there are both positive and negative costs and the effect of substitution of these costs was confirmed. We did not consider the subjective value of price chain.

We see the role of transport and logistics in the field of export transaction from the perspective of the process of transfer of ownership and optimizing speed and quality of delivered goods. The benefits can be seen from the perspective of the field of information and communication technologies (process of information about current position and status of goods, etc.). The biggest benefit of this research is in providing an open space in the production of smart connected products [21].

This statement is based on Porter's idea [2]. Porter says that it will be necessary to examine the business models of production the connected smart products in terms of competitiveness and the transaction leading to a change of ownership for products manufactured in this way. 


\section{References}

[1] PORTER, M. E.: Competitive Advantage: Creating and Sustaining Superior Performance. New York: Free Press. 1985. 569 p., ISBN 0-684-84146-0.

[2] PORTER, M. E., HEPPELMAN, J. E.: How Smart Connected Products are Transforming Competition. New York: Harvard Business Review, Nov. 2014.

[3] COASE, R. H.: The Nature of the Firm, Economica, 2007. vol. 4, No. 16, pp. 386-405, 1937.

[4] COASE, R. H.: The Firm, the Market and the Law [Mimeo], Chicago : University of Chicago Press, 1988.

[5] WILLIAMSON, O. E.: The Economic Instructions of Capitalism. Tubingen : Mohr. 1990, 452 p., ISBN 3-16-145612-2.

[6] RADELEC, S., SACHS, J.: Shipping Costs, Manufactured Exports and Economic Growth [Mimeo], Cambridge: MA: Harvard University. 1998.

[7] HUMMELS, D.: Time as a Trade Barrier [Mimeo], Lafayette : University of Purdue, 2001.

[8] HUMMELS, D.: Transportation Costs and International Trade in the Second Era of Globalization, J. of Economic Perspectives. 2007, vol. 21, No. 3, pp. 131-154.

[9] KALEKA, A.: Studying Resource and Capability Effects on Export Venture Performance, J. of World Business. 2012, vol. 47, No. 1, pp. 93-105.

[10] BEHNAM, A., BEHNAM, L.: The Cost of Exchange, St. Louis: Ronald Coase Institute, Working Paper Number 1, 2001.

[11] WALLIS, J. J., DOUGLASS C. N.: Measuring the Transaction Sector in the American Economy, 1870-1970, Engerman and Gallman, 1986, pp. 95-161.

[12] EGGERTSSON, T.: Economic Behavior and Institutions, Cambridge: Cambridge University Press., 1990.

[13] BRAKMAN, S., GARRETSEN, H., MARREWIJK, CH., WITTELOOSTUIJN, A.: Nations and Firms in the Global Economy, Cambridge: Cambridge University Press. 2009, 425 p., ISBN 978-0-521-54057-5.

[14] FINDLAY, R., O ' ROURKE, J.: Commodity Market Integration [Working Paper No. 8579], Cambridge (MA) : NBER, 2001.

[15] NELSON, C. A.: Export Import: How to Take Your Business Across Borders. New York: McGraw-Hill 2009, 398 p., ISBN 978-0-07$148255-4$.

[16] ROJICEK, M.: Impact of Globalization on the Functioning of International Trade (in Czech), Politicka ekonomie, 2012, vol. 60, No. 2, pp. 187-207.

[17] HANSENOVA, H., MINARIK, M., FURDOVA, L.: Transport and its Impact on Transaction Costs in Export Prices - Draft of Model of Export Prices. Prispevek prezentovany na konferenci Cesko a Slovensko v mezinarodnim obchode a podnikani, Praha, 2012.

[18] MINARIK, M.: Transaction Costs and Their influence on the Competitiveness of the Slovak and EU Export (dissertation, supervisor Hansenova, H.), 2014.

[19] CEMPIREK, V., HANSENOVA, H.: Transaction Costs in the Export Price (in Czech), Proc. of conference LOGI 2013, Ceske Budejovice, 2013.

[20] CEMPIREK, V., SIROKY, J.: Technical and Technological Solution for Asia-Europe Railway Connection (in Czech), 8 p., Sbornik anotaci z workshopu Kontejnerova zeleznicni doprava mezi Evropou a Asii, VUT: Brno, 2014, ISBN 978-80-214-4964-0.

[21] HANSENOVA, H., CEMPIREK, V., NOVAK, P.: Sustainable Transport and Logistics and their Impact on Transaction Costs in the Export Price (in Czech), Sbornik prednasek, Verejna osobni doprava 2015, pp. 106-112, 2015. ISBN 978-80-89565-20-7. 